\title{
“КРУГ ГЕОГРАФИИ" И СУДЬБА АНТРОПОГЕОГРАФА (К 150-ЛЕТИЮ СО ДНЯ РОЖДЕНИЯ ВЕНИАМИНА ПЕТРОВИЧА СЕМЁНОВА-ТЯН-ШАНСКОГО)
}

\author{
(C) 2020 г. П. М. Полян ${ }^{a, b}$, * \\ ${ }^{a}$ Национальный исследовательский университет “Высшая школа экономики”, Москва, Россия \\ ${ }^{b}$ Институт географии Российской академии наук, Москва, Россия \\ *e-mail: pavel.polian@gmail.com \\ Поступила в редакцию 12.04.2020 г. \\ После доработки 30.05.2020 г. \\ Принята к публикации 06.06.2020 г.
}

\begin{abstract}
Статья посвящена 150-летию со дня рождения выдающегося российского географа Вениамина Петровича Семёнова-Тян-Шанского (8 апреля 1870 г. - 10 февраля 1942 г.). В ней отмечены узловые моменты его научного становления, одним из ключевых в ряду которых можно считать “Круг географии”, открытый и разработанный ученым в 1913 г. и определивший основные вехи его последующей эволюции до самой смерти в блокадном Ленинграде (этот “Круг” ученый хотел видеть высеченным на своем надгробии). Впервые вводится в научный оборот набросок текста “О выпадающих отделах при принятой системе деления географии на математическую, физическую, экономическую и политическую” (датированный 21 апреля 1937 г.), оказавшийся во многом пророческим. Прослежены основные направления посмертного восприятия и высокой оценки географического наследия В.П. Семёнова-Тян-Шанского его научными современниками и потомками, показана преемственность по отношению к нему теоретико-географического творчества Б.Б. Родомана. Обосновывается необходимость комментированного издания избранных работ В.П. СемёноваТян-Шанского, в которое вошли бы его главные труды - как опубликованные (“Район и страна”), так и не опубликованные (“Географические законы. Опыт высшей географии”).
\end{abstract}

Ключевые слова: В.П. Семёнов-Тян-Шанский, биография, теоретическая география, антропогеография, Б.Б. Родоман, история географии

DOI: $10.31857 / \mathrm{S} 2587556620050131$

\section{ВВЕДЕНИЕ}

8 апреля 1870 г. - 150 лет тому назад - родился Вениамин Петрович Семёнов-Тян-Шанский (рис. 1.). Его, как и его отца, сенатора и члена Госсовета Петра Петровича Семёнова-Тян-Шанского, можно смело поставить в первый ряд выдающихся отечественных географов.

И отец, и сын присягнули географии еще в самом нежном возрасте: первый, - играя в "географическое лото”, а второй, - стоя в детской кроватке и впитывая глазами карту полушарий Ильина. Вместе с тем оба являют собой два принципиально разных этапа развития российской географии в целом, а заодно и Русского географического общества (РГО).

П.П. Семёнов-Тян-Шанский обессмертил себя и вне географии, а именно активным участием в реформах Александра II по освобождению крестьян и выводом российской статистики на мировой уровень с проведением первой переписи на- селения в 1897 г. Обессмертил себя и в своих детях, научные интересы которых (а все пятеро ученые) восходят к его урокам: Дмитрий - статистик, Андрей - зоолог, энтомолог и переводчик Горация, Вениамин - наш герой, Ольга - этнограф и художница, Измаил - метеоролог.

В географии же П.П. Семёнов-Тян-Шанский один из ярких представителей “второй волны” эпохи Великих географических открытий, когда после первой волны (XIV-XVII вв.) собственно белых пятен на Земле уже не оставалось (почти!), а вот открытых, но плохо изученных и недостаточно хорошо закартированных - с пол-Земли и больше. В ситуации перманентной борьбы метрополий за расширение сталкивающихся периферий своих империй географические экспедиции, - казалось бы: банальные вылазки в красивые места за новыми знаниями! - становились своего рода “мягкой силой”, не водружающей флаги, но приручавшей земли. 


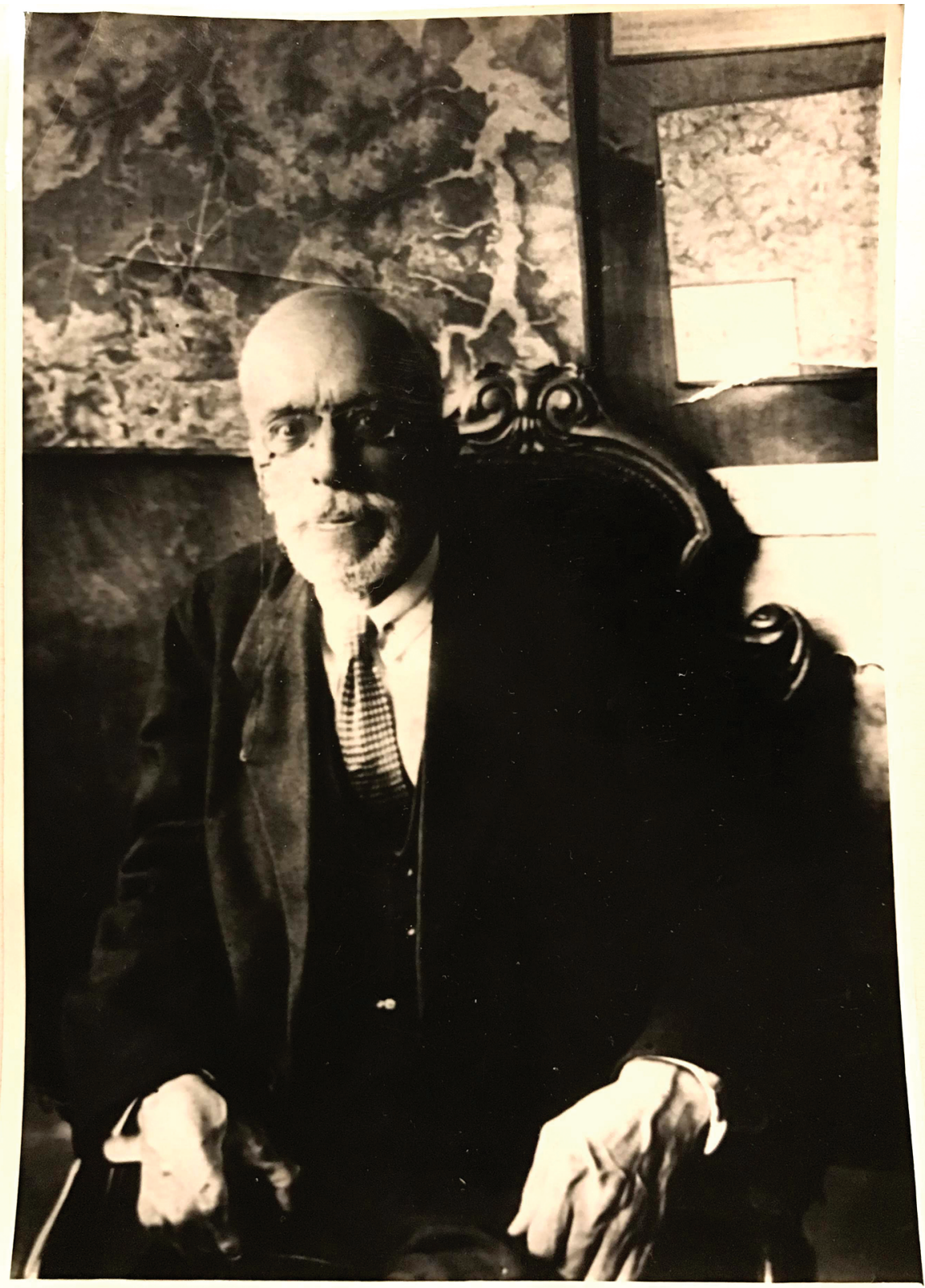

Рис. 1. В.П. Семёнов-Тян-Шанский. Ок. 1940.

Это придавало таким путешествиям, как семёновское на Тян-Шан в 1856-1857 гг., пряный геополитический привкус и делало их чрезвычайно приветствуемыми не только наукой, но и короной. И десяти лет не прошло после начала той экспедиции, как значительная часть киргизского Тян-Шана (современный Тянь-Шань) была благосклонно и благополучно принята под российский скипетр. И недаром, спустя полвека, в ноябpe 1906 г., Николай Романов, последний российский монарх, нарастил фамилию Семёнов на “Тян-Шанский” [8], а не, скажем, на “-Мураевен- ский”, хотя Мураевенской волости Рязанской губернии у тамошнего экс-помещика Семёнова посвящено куда как более глубокое исследование. Не случайно и то, что П.П. Семёнов-Тян-Шанский всю жизнь интересовался колонизационной политикой России, писал о ней, радовался ее успехам и искренне переживал неудачи. В этом смысле ему очень повезло со смертью в феврале 1914 г.: она избавила его от непосильного бремени лицезреть вереницу событий, состоящих из поражений Первой мировой, отречения царя и обеих российских революций 1917 г. 


\section{"КРУГ ГЕОГРАФИИ" \\ В.П. СЕМЁНОВА-ТЯН-ШАНСКОГО}

Патриотом Российской империи был и Вениамин Петрович Семёнов-Тян-Шанский - и не просто патриотом, но и методологом патриотизма! В 1915 г. он опубликовал в "Известиях Императорского РГО” превосходную статью “О могущественном территориальном владении применительно к России" [47] - о типологии империй с точки зрения их пространственных структур и о преимуществах российского типа "от моря до моря”. Обобщающе-теоретический характер этой статьи, ее бросающийся в глаза геополитизм и картографические новации, в частности, первые в географии “картоиды” (рис. 2), маркируют уже новый этап в истории российской географии, с которым ассоциируется Семёнов-сын. На смену эмпирическим штудиям и отчетам (но и не отменяя их!), пришли попытки полимасштабного обобщения и осмысления эмпирики, ее классификации и синтезирования вплоть до выдвижения методических и теоретических конструктов.

Колоссальное впечатление на отечественных географов оказала книга Д.И. Менделеева "К познанию России” (1906), в том числе и применением первых количественных методов, а именно центрографии. Сам же В.П. Семёнов-Тян-Шанский выступил с прорывной для того времени монографией “Город и деревня в Европейской России" [46], где впервые сформулировал постулаты того, что сегодня называется геоурбанистикой, а также обозначил новаторские принципы дазиметрических карт. С превращением российской географии в научную дисциплину мейнстрим теоретизации постепенно обживался в повестке научных заседаний Императорского Русского географического общества и в содержании его “Известий”, все более и более тесня отчеты об экспедициях.

В 1913 г. В.П. Семёнов-Тян-Шанский выдвинул концепцию так называемого "Круга географии” (рис. 3) - революционной модели, соединявшей в единое целое весь разношерстный понятийный аппарат [48].

Собственно, это не круг, а шестиугольник, вписанный в круг. В его углах - три основные оболочки земли (суша, вода и воздух - внизу) и три производных солнечного света и теплоты (растения, животные и человек - вверху). 15 линий между вершинами гексагона - это внутренние комбинации связей между базовыми узлами.

"Круг географии" - высшее научное озарение В.П. Семёнова-Тян-Шанского, по его собственному признанию. Сам ученый прочил этому понятию призвание сыграть в самоидентификации и внутренней систематике географии такую же роль, какую таблица периодических элементов Д.И. Менделеева сыграла в химии.
Этого, правда, не произошло, если не считать случая самого Вениамина Петровича: "На основании этого круга географии я впоследствии написал (в рукописи) книгу "Географические законы”, или "Опыт высшей географии", которую я считаю своим высшим географическим литературным достижением. География, несомненно, в общем, наука синтетическая. Но для того, чтобы правильно построить этот синтез, необходимо предварительно произвести географический анализ частей, его составляющих. Он и дается в моей схеме 15 пространственных взаимных связей географических элементов. Из этого анализа совершенно ясно, что и в какой степени важно и что неважно (типично и нетипично) для правильного построения географического синтеза или ландшафта" [60, т. 1, с. 594].

Не без экстравагантности он писал в мемуарах: "Полагаю, ито он вполне мог бы быть вырезан, вместо эпитафии, на моей гробнице...” [там же]. А в 1941 г. он даже набросал эскиз надгробия, какое хотел бы видеть на своей могиле (рис. 4). Это стилизованный финский валун-глыба, на заполированной части которого вместе с именами Вениамина Петровича и его жены ${ }^{1}$ был бы выбит - да, да: “Круг географии”!

Для самого В.П. Семёнова-Тян-Шанского "Круг” действительно стал краеугольным камнем научных воззрений и занятий на всю отпущенную ему жизнь, венцами которых после революции стали основанный Вениамином Петровичем Центральный географический музей в Ленинграде (ЦГМ, 1919-1941 - [29-32]) и его итоговые теоретические работы, воплотившиеся в двух книгах "Район и страна" (писалась в 1917-1924 гг., вышла в 1928 г., увы, в неполном виде - [51]) и "Географические законы. Опыт высшей географии" $\left(1939\right.$, не вышла ${ }^{2}$. И за музей, и за свое антропогеографическое учение Вениамин Петрович получил не благодарность и звания, а травлю и выдворение из ЦГМ в 1936 г. Впрочем, никаким более серьезным репрессиям В.П. Семёнов-ТянШанский не подвергался.

\section{ГЕОГРАФИЯ НАСЕЛЕНИЯ В СИСТЕМЕ ГЕОГРАФИЧЕСКИХ ДИСЦИПЛИН}

В этой связи крайне интересен цельный набросок “О выпадающих отделах при принятой системе деления географии на математическую, физическую, экономическую и политическую”, датированный 21 апреля 1937 г. Запечатлев в нем смену парадигм и реструктуризацию географии, В.П. Семёнов-Тян-Шанский похвалил и Географическое общество за подобающую реструктуризацию своих комиссий. В то же время острое по-

\footnotetext{
${ }^{1}$ Вера Александровна Семёнова-Тян-Шанская умерла 2 мая 1940 г.

2 Архив РГО. Ф. 48. Оп. 1. Д. 79 и 93.
} 


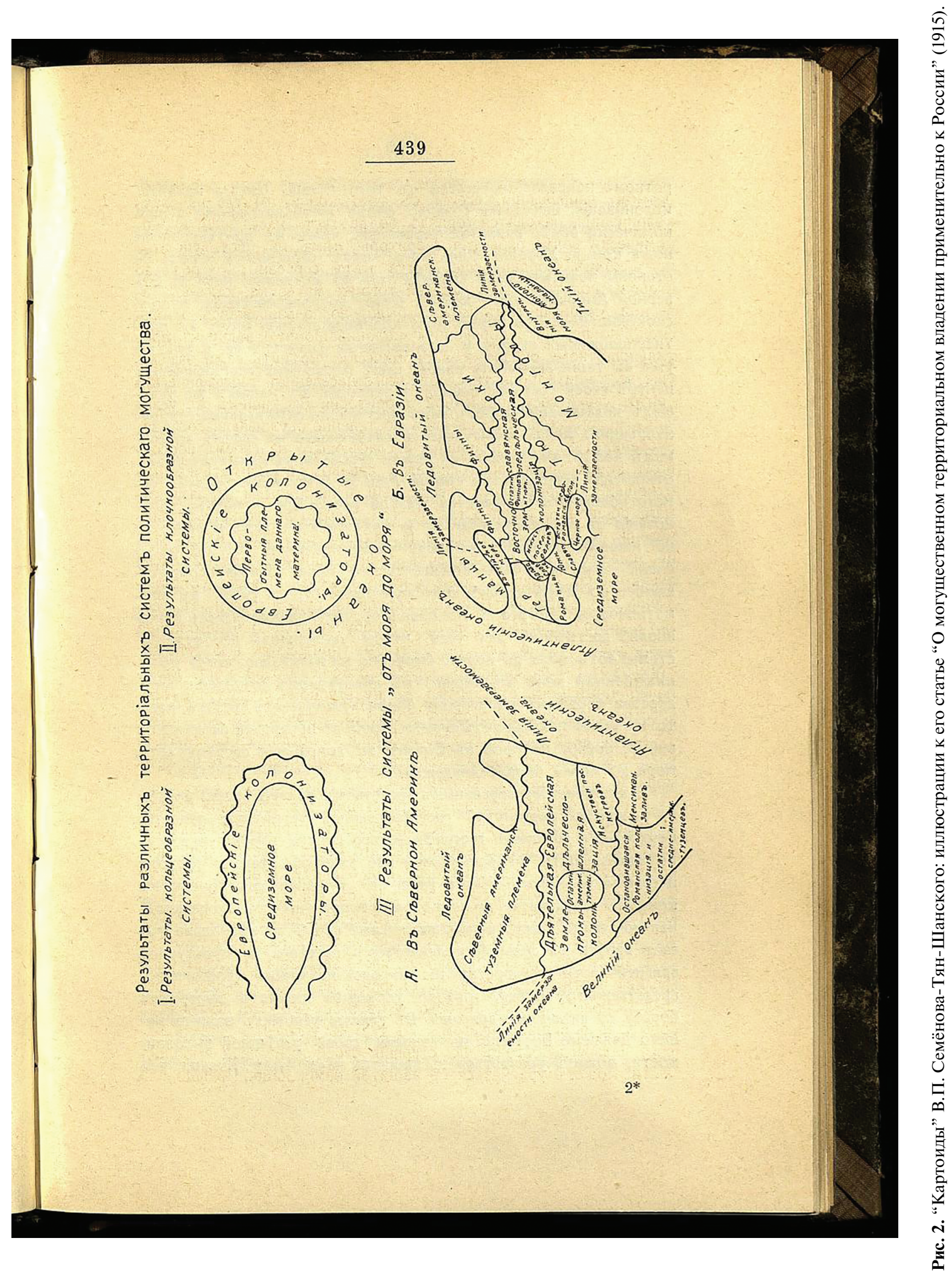




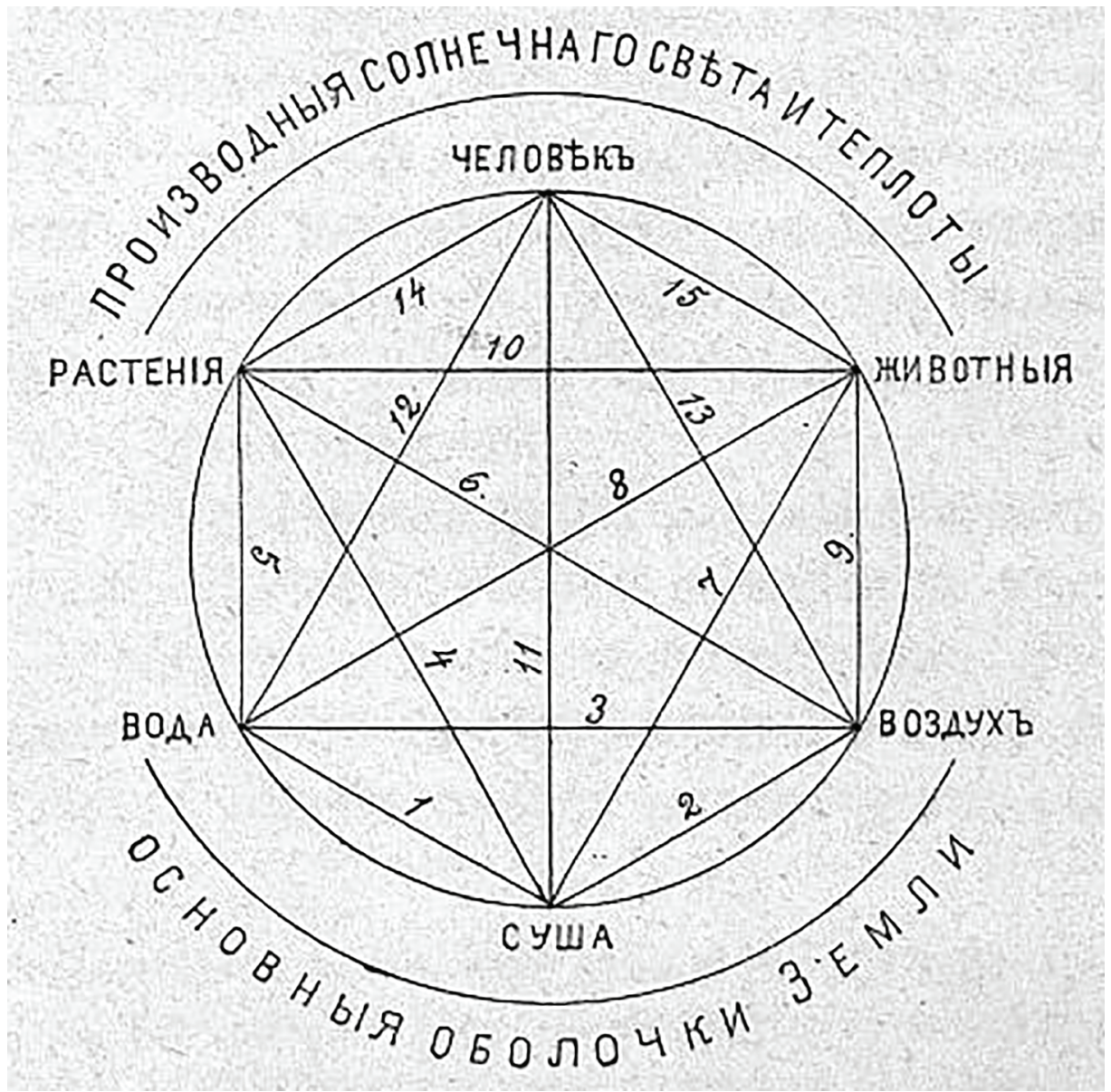

Рис. 3. “Круг географии” В.П. Семёнова-Тян-Шанского. Иллюстрация к его статье “Что такое география? ” (1915).

нимание дефектности и обновившейся структуры заставляло его указать на то, чего в ней недостает, а именно географии населения.

“Прав Н.Н. Баранский, когда он указывает, ито при существующем грубом делении физическая география становится "бесчеловечной", а экономическая география - "противоестественной" и что физико-географы и эконом-географы сидят друг к другу спиной и не желают даже обернуться ${ }^{3}$.

Географию населения нельзя ни малейшим образом смешивать с демографической статистикой, с этнографией, с антропологией и с исторической географией.

<...> Пятилетки соцстроительства и колхозное движение с огромной быстротой перемещают ныне массы населения на территории СССР. Такой быстроты и размаха не знала еще ни одна страна $в$ мире. Это грандиозное географическое явление никем, однако научно не изучается, да и не может изучаться при неимении где бы то ни было специаль-

\footnotetext{
3 Это место показывает, что мысли, проступившие у Н.Н. Баранского в 1946 г. в статье [3], сложились у него как минимум десятилетием ранее.
}

ного места для географии населения. Подробного систематического учета этого явления не ведется ни картографически на топографических картах крупного масштаба, ни посредством периодических исчерпывающих списков населенных мест. Чисто практические работы планировочных учреждений по выработке проектов обращения существующих городов Союза и “большие социалистические города", как показал опыт Ленинграда, требуют постановки специальных полевых и камеральных научных исследований по географии населения планируемых территорий, чего без подготовленных работников-географов сделать нельзя. Несомненно, Академии Наук СССР нельзя не остановиться самым пристальным образом на этом вопросе.

Таков совершенно необходимый соединительный мост между физической и экономической географией. Чем скорее он будет воздвигнут, - тем лучше"4.

Такое “лоббирование” вопроса о статусе географии населения походило на реинкарнацию антропогеографии и было само по себе весьма

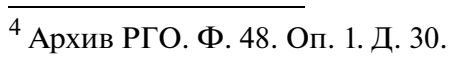




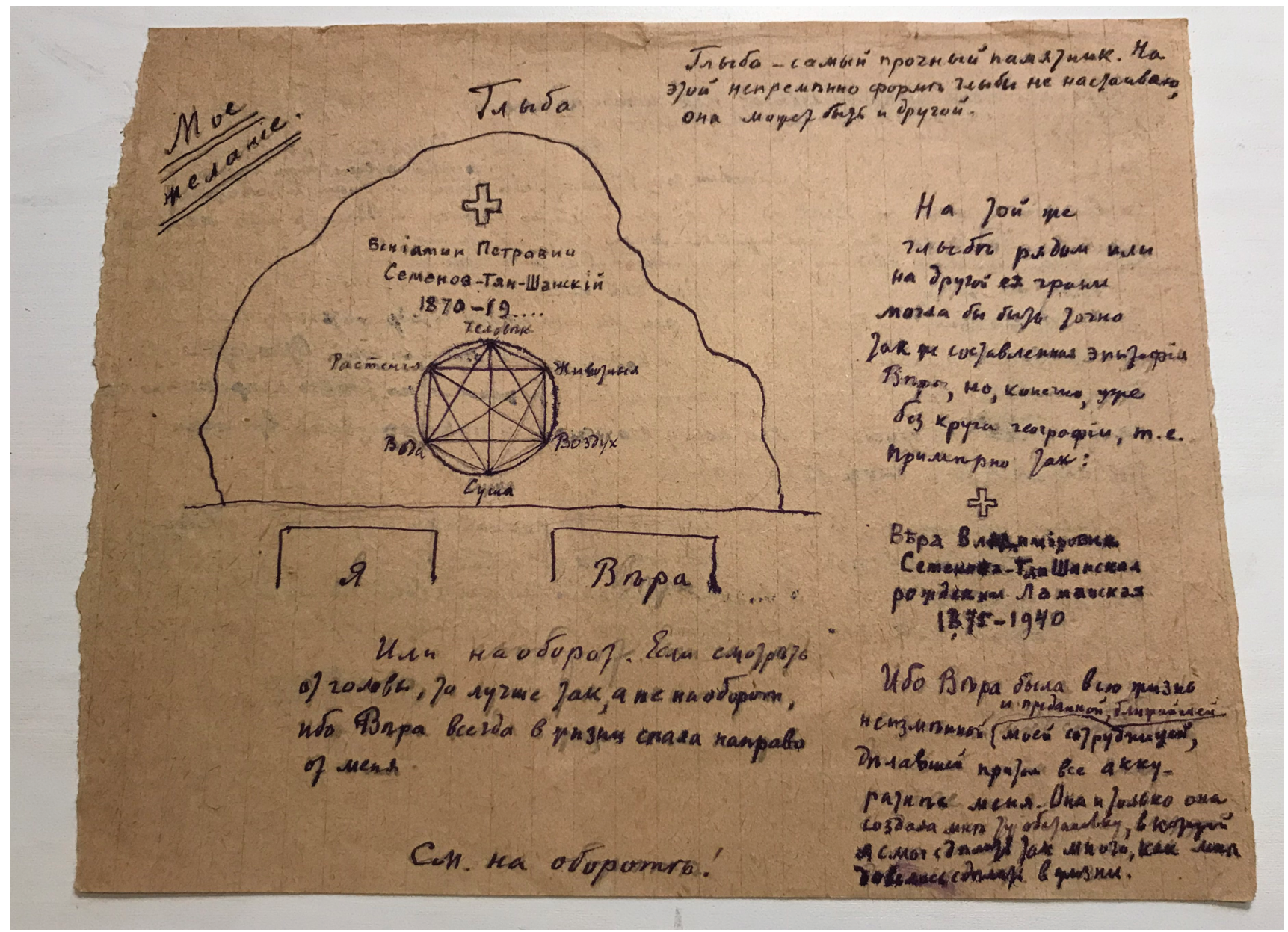

Рис. 4. “Круг географии” на выполненном В.П. Семёновым-Тян-Шанским эскизе собственного надгробия. 1941.

смелым: ведь еще на стыке 1920-х и 1930-х годов антропогеографию в СССР заклеймили, а географию в целом прочно приковали за оба крыла к двум утесам - народному хозяйству (экономическая география) и природе и природным ресурсам (география физическая). Приковали настолько прочно, что и многие десятилетия спустя покушаться на иное не приходило в голову. Так, И.М. Маергойзу, ученому смелому и внутренне свободному, в первой половине 1970-х годов усиленно работавшему над оригинальной теорией территориальных структур, даже в голову не приходило, что для экономико-географа возможна хоть какая-то альтернатива производственной географии и народному хозяйству как ее системному объекту, в рамках которого - и под гнетом которого, - он оперировал в своих построениях. Да и (экономико)-географическое положение у того же Маергойза было все с той же печатью “экономической". Внесение же в “бюллетень" чего-то третьего - той же "географии населения" - наращивало бы степени свободы и неизбежно подталкивало бы к универсализму, к син- тезу и к гуманизации как экономико-, так и физико-географического подходов ${ }^{5}$.

Предмет датированного 1937 г. наброска В.П. Семёнова-Тян-Шанского "О выпадающих отделах..." явно находился в фарватере его размышлений и работы над рукописью “Географических законов". Он не был им опубликован, а скорее всего не было и попытки такой публикации. Дразнить марксистских гусей не хотелось, да и впрямь было рискованно.

И тем не менее В.П. Семёнов-Тян-Шанский был некоторым образом “услышан”!...

В 1946 г. вышла статья Н.Н. Баранского “Страноведение и география физическая и экономическая" с ее знаменитым воплем "Человека забыли!!! ". Строй ее мыслей необычайно близок настроениям В.П. Семёнова-Тян-Шанского:

\footnotetext{
${ }^{5}$ То, что в России, в силу ресурсной доминанты ее экономики, оба “утеса" теснее связаны, не меняет сам принцип их разнесенности по разным научным рубрикаторам. Исторически у руля всей географией были преимущественно представители физико-географического “крыла”.
} 
“...Физическая и экономическая география находятся у нас в чрезвычайно большом между собой разрыве, несравненно большем, чем в любой другой стране мира и чем это было у нас в старое время" [3, с. 11]. С сожалением констатируя уход в мир иной географов-универсалов, знавших толк как в природной, так и в человеческой географии, в их числе и В.П. Семёнова-Тян-Шанского, Н.Н. Баранский обвиняет в глубине этого разрыва тех, для кого антропогеография была излюбленным бранным словом, - «недоброй памяти леваков, орудовавших на фронте экономической географии в 1929-1934 гг. <...> Запугав и экономгеографов и физикогеографов, леваки сделали первых "противоестественными", а вторых "бесчеловечными" <... Убив старую "антропогеографию", "новые веяния" ничего нового не создали на ее месте; раздел о населении... выпал бесследно, провалившись между природой и хозяйством, между физической и экономической географией. Человека забыли...» [3, с. 11-12].

И тем не менее справедливость поставленного В.П. Семёновым-Тян-Шанским вопроса взяла свое. В конце 1945 г. в Московском филиале ВГО была создана Комиссия географии населения и городов, начавшая свою работу 25 декабря 1945 г. с доклада ее организатора и первого председателя P.М. Кабо по теме "Природа и население в их взаимодействии как предмет географии" 6 . В первое послевоенное 10-летие произошел несомненный всплеск первоклассных публикаций именно в области географии населения (статьи И.М. Маергойза, Л.Е. Иофы, Г.М. Лаппо и других).

Колеса нынешней ВАКовской “квадриги” (специальность 25.00.24 "Экономическая, социальная, политическая и рекреационная география") разъехались во все стороны. Между тем анализ А.И. Трейвиша показал, что в сознании самих “экономико-географов" ведущим в наше время стало не экономическое, а общественное колесо: "общественная география" (или, чуть полнее, "география человека и общества", она же "антропосоциогеография” в греко-латинской версии) таково самоназвание специалистов, остепененных по версии ВАК [63].

\footnotetext{
${ }^{6}$ Первым председателем этой Комиссии был Кабо - до 1952 г. В 1952-1956 гг. ее возглавлял В.В. Покшишевский, в 19561978 гг. - В.Г. Давидович, в 1978-1982 гг. - С.А. Ковалёв, 1983-2000 гг. - Б.С. Хорев, с 2000 г. и по настоящее время А.И. Алексеев. Сама комиссия несколько раз меняла названия: 1945-1963 гг. - Комиссия географии населения и городов, 1964-1972 гг. - Комиссия географии населения, 1983-1996 гг. - Комиссия географии населения и поселений, с 1996 и по настоящее время - Комиссия социальной географии, географии населения и поселений $[64$, с. $227 ; 1$, c. 537]. В 1960-1970-е годы в рамках МФГО СССР одновременно функционировал семинар по урбанизации, организованный И.М. Маергойзом (после его смерти в 1975 г. семинар возглавлял Ю.Л. Пивоваров).
}

Что это как не латентный ренессанс антропогеографических представлений В.П. СемёноваТян-Шанского?

\section{“ТО, ЧТО ПРОШЛО...”: ПОСЛЕДНИЕ ГОДЫ ЖИЗНИ УЧЕНОГО}

До конца жизни В.П. Семёнов-Тян-Шанский оставался в душе человеком эпохи своего отца консерватором, сердившимся на новое правописание, верившим в общину как в венец крестьянского раскрепощения и не верившим в столыпинские реформы. Оставался он и империофилом, отчего искренне, неконъюнктурно приветствовал советские аннексии 1940 г. и войну с Финляндией, воспринимая все это как некий естественный возврат России - пусть и под псевдонимом СССР - к своим дореволюционным “берегам”.

Не догадываясь о преступном корне этих событий (секретном протоколе к советско-германскому пакту о ненападении), он не учуял в них завязь грядущей беды - войны, которая, докатившись с разных сторон до Ленинграда, обернулась блокадой, унесшей, наряду с миллионом других, и его жизнь.

Последнюю, 18-ю, главу своих мемуаров “То, что прошло...” (рис. 5), Вениамин Петрович писал в январе 1942 года и назвал ее так: “Всемирная война: 1941-194...” [60, т. 2, с. 411-416].

Самыми последними словами в них были: “ Вo время немецкой осады в Ленинграде скончались при сильнейших морозах, немилосердно уничтожсавших и немиев, такие массы народа, что не успевали хоронить и вначале складывали штабелями покойников. Вот что значит вовремя не эвакуировать население. Тотчас после похорон брата Измаила несчастья стали прилагаться и непосредственно к моему лииу ${ }^{7}$. Так...”.

А что именно “так” - уж не узнать: это последняя запись в воспоминаниях Вениамина Петровича.

Он скончался от дистрофии 10 февраля 1942 г. ${ }^{8}$ Старший сын сколотил из отцовского письменного стола гроб и похоронил отца на Богословском кладбище на Выборгской стороне. Эскиз валуна с “Кругом географии” решительно не пригодился!..9

\footnotetext{
${ }^{7}$ Вениамин Петрович здесь каламбурит: в конце января 1942 г. он упал на улице и сильно разбил лицо.

${ }^{8}$ А 8 апреля 1942 г., в день рожденья В.П. Семёнова-ТянШанского, умер его старший брат Андрей.

${ }^{9}$ В настоящее время Фонд наследия П.П. Семёнова-ТянШанского при поддержке географической общественности инициировал установку мемориальной доски Вениамина Петровича, на доме 12 по 4-й линии Васильевского острова в Санкт-Петербурге, в котором ученый прожил последние 24 года своей жизни.
} 


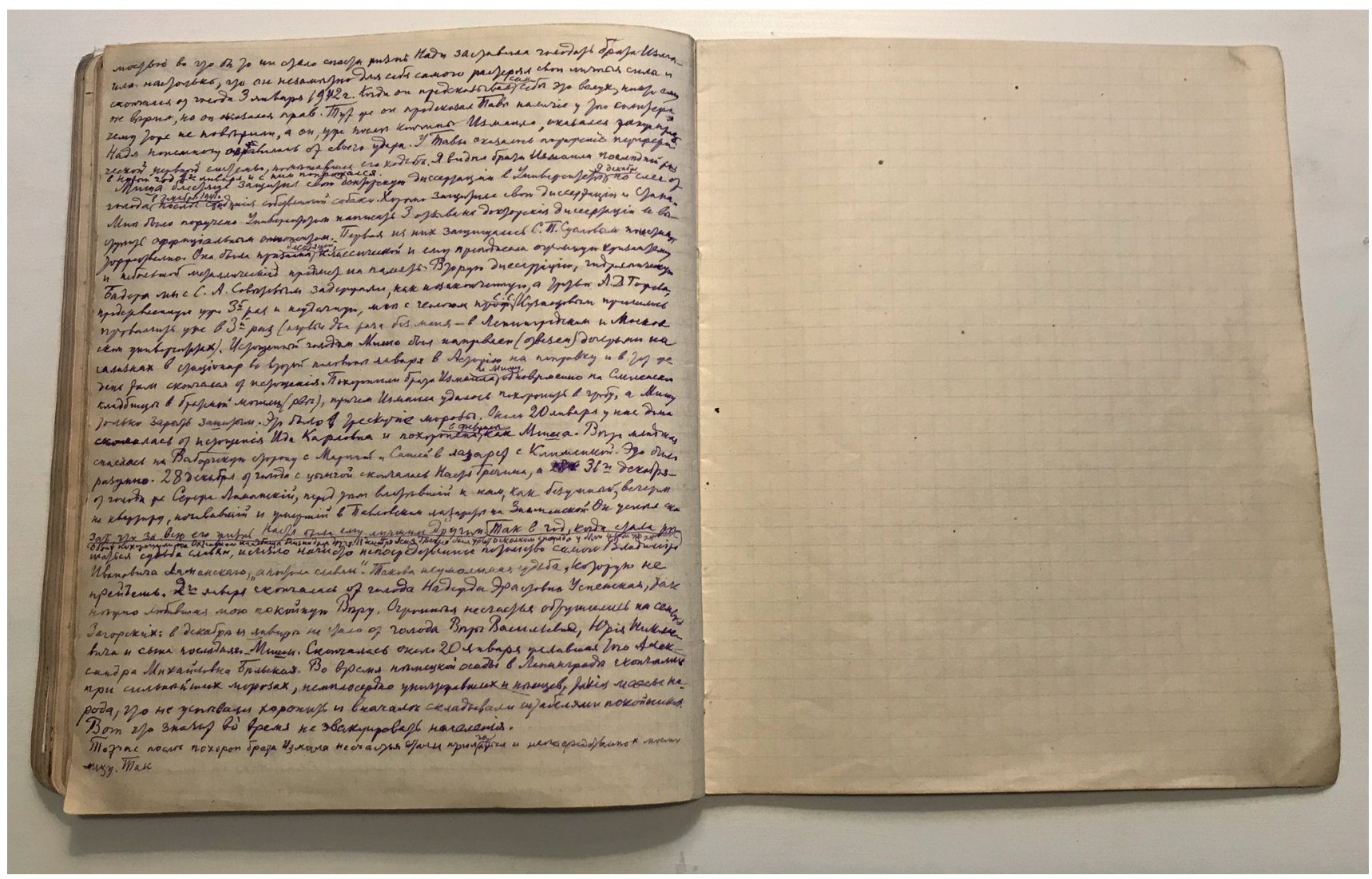

Рис. 5. Последняя страница мемуаров В.П. Семёнова-Тян-Шанского “То, что прошло”. 10 февраля 1942 г.

\section{РЕЦЕПЦИЯ НАУЧНОГО ТВОРЧЕСТВА В.П. СЕМЁНОВА-ТЯН-ШАНСКОГО}

Если не считать директорства в ЦГМ, В.П. Семёнов-Тян-Шанский не занимал административно-командных высот в российской или советской географии. Но лучшие обобщающие послевоенные работы советских профессоров, не колеблясь, ставили его в ряд буржуазных ученых не таких, конечно, монстров, как западные антропогеографы и геополитики (Э. Реклю, В. де ла Блаш, Ф. Ратцель, А. Геттнер, Х. Дж. Макиндер и др.), а скорее таких чудаков, как его отец, в тень которого Вениамина Петровича всегда норовили задвинуть [42].

Вместе с тем В.П. Семёнов-Тян-Шанский, безусловно, входил в ту не слишком большую группу ученых первого класса, юбилеи и смерти которых отмечались в географической периодике "Laudatio" или некрологами. О нем в этом качестве писали, в частности, Н.Н. Баранский и В.В. Покшишевский (некрологи: [2, 27]), Л.С. Берг (к 25-летию научной деятельности и к 70-летию), Е.Е. Святловский и А.А. Бобрик (к 35-летию научной деятельности), О.А. Константинов и С.А. Ковалёв, В.П. Коровицын, Н.Я. Ковальская и Ю.Г. Саушкин (к 100-летию со дня рождения),
В.Е. Борейко (к 120-летию со дня рождения) [2, 4, 5, 7, 9, 10, 23, 24, 45], Ю.Г. Саушкин [44]. Обозначен был и 150-летний юбилей ученого [11, 35-37, 61].

Особенность случая В.П. Семёнова-ТянШанского в том, что потомки реагировали не только на его личные юбилеи, но и на юбилеи выхода его главных научных трудов - 75-летие "Города и деревни в Европейской России" [12, 28, 33] и 50-летие "Района и страны" [21, 22, 65]. И даже отдельных тем или методов: в частности, топонимики [39], музееведения [16, 30-32] или дазиметрических карт [26, 34, 38]!

Начиная с 1979 г., когда вышла статья В.Л. Каганского, П.М. Поляна и Б.Б. Родомана, посвященная 50-летию выхода в свет "Района и страны” и рефлексии на него [19] ${ }^{10}$, о В.П. Семёнове-Тян-Шанском вспоминают регулярно, хотя и не слишком часто. Его работы и идеи находили отклик не только у географов, но и у экологов и природоохранителей [10], а в последнее время - все чаще и у политологов [13-15].

\footnotetext{
${ }^{10}$ В своем аудиоинтервью Ю. Самодурову от 2013 г. Родоман назвал эту статью “археорецензией” (см. в сети: http://oralhistory.ru/talks/orh-1636.pdf).
} 
В области теоретической географии В.П. Семёнов-Тян-Шанский не оставил прямых учеников. Зато в лице Б.Б. Родомана он обрел себе в потомках превосходного продолжателя своего теоретико-географического направления [42, 43]. Конечно, считать Родомана, при всей его индивидуальности и оригинальности, истинной реинкарнацией Вениамина Петровича было бы преувеличением, но не таким уж большим ${ }^{11}$.

Встреча с текстами В.П. Семёнова-Тян-Шанского, а точнее с “Районом и страной”, состоялась у Родомана необычайно рано, еще в студенчестве: «Книгу ВПСТШ "РиС" я использовал в дипломной работе (заимствованный и переработанный мною рисунок) $)^{12}$ и в статье 1956 г. ${ }^{13}$ Эта и другие важные для меня книги (Геттнер, Бунге, Хаггет) несколько десятков лет имелись в моей домашней библиотеке, но все куда-то исчезли. Ни одну из этих книг я не прочитал, не изучил целиком; я в них только заглядывал и что-то выхватывал» ${ }^{14}$.

Но картоиды - не главное, что связывает Б.Б. Родомана с В.П. Семёновым-Тян-Шанским как с теоретико-географом. Куда принципиальнее такой “родовой признак”, как установка на синтез географии природы и обшества. Да Родоман и сам не открещивается от такого родства: "Своим предшественником в России я считаю В.П. Семёнова-Тян-Шанского” [42, с. 244] ${ }^{15}$. С ним солидаризуется и В.Л. Каганский: “Для В.П. Сeмёнова-Тян-Шанского - такова и методологическая позиция и конкретные работы предшественника теоретической географии - география челове$к а$ не противостоит географии природы, а вершает

\footnotetext{
${ }^{11}$ Маленькая, но говорящая деталь: Б.Б. Родоман даже приставку к своей фамилии себе присвоил - "Родоман-Хамар-Дабанский” (за феноменальный переход через хребет Хамар-Дабан в Бурятии в 1953 г.). Правда, за неимением монарха, он был вынужден издать высочайший эдикт об этом сам, а из природной скромности пользовался данной фамилией крайне редко.

${ }^{12}$ Способы типологического и регионального районирования и их изображение на карте” (1955). Надо полагать, что Родоман положил глаз на генерализованные картосхемы типов территориального могущества В.П. - явные прообразы родомановских “картоидов".

${ }^{13}$ См.: [41].

${ }^{14}$ Из электронного письма Б.Б. Родомана П.М. Поляну, от 6 апреля 2020 г. В телефонном разговоре от 10 апреля Родоман поделился со мной темой своих текущих размышлений и будущего доклада: “Невидимые аспекты поляризованного ландшафта". Суть в том, что вся его старая концепция нуждается в пересмотре, ибо все размывается страшно, а ежели так, то как можно тогда говорить об ареалах как о константах?

${ }^{15}$ Ср. в другом месте: “В.П. Семенов-Тян-Шанский подчеркивал решаюшую роль “жизнетворного неравенства" и всякого рода неравномерности для поддержания жизни на Земле" [42, c. 79].
}

(sic.') ее; культурный ландшафт оформляет природный и включает его в себя" [20, 25] ${ }^{16}$.

Между тем публикация 1979 года вызвала ощутимый резонанс, пробудив интерес и к другим произведениям В.П. Семёнова-Тян-Шанского прежде всего к “Городу и деревне в Европейской России”, а также к его неопубликованному наследию, особенно к мемуарам. Одна за другой стали выходить посвященные ему статьи и публикации его текстов, как неизданных [40, 52, 55], включая главы из воспоминаний, так и ранее уже опубликованных; в частности, “О могушественном территориальном владении применительно к России” - неоднократно перепечатывалось [56, $59,61]$.

10 января 1984 г. в Московском филиале Географического общества СССР состоялось совместное заседание семинара по урбанизации и комиссии географии населения и поселений заседание, посвященное 75-летию выход “Города и деревни...”. В дискуссии, последовавшей за докладом П.М. Поляна об этом произведении В.П. Семёнова-Тян-Шанского, приняли участие А.И. Алексеев, С.А. Ковалёв, Н.В. Петров, О.А. Константинов, Н.В. Тагеева (сестра невестки Вениамина Петровича), О.А. Александровская, Я.Г. Машбиц и Ю.Л. Пивоваров [12] ${ }^{17}$.

Книга “Город и деревня...” В.П. СемёноваТян-Шанского представлялась, помимо всего прочего, еще и своего рода подведением итогов эволюции расселения в Европейской России за весь XIX в. В 1999 г., в преддверии нового века, родилась идея создания аналогичного “отчетарифмы” за век XX-й; дальнейшее было далеко не “делом техники", но тяжелой составительской, редакторской и авторской работой, подхваченной “Новым издательством”. Но книга срослась очень быстро и вышла уже летом 2001 г. [17].

В 2009 г. в издательстве “Новый хронограф" вышли воспоминания Вениамина Петровича “То, что прошло", составленные и откомментированные М.А. Семёновым-Тян-Шанским, вну-

\footnotetext{
${ }^{16} Э$ та публикация является римейком более ранней статьи [19], но приведенная цитата в материнской публикации отсутствует. Обращает на себя внимание то, что В.П. Семёнов-Тян-Шанский назван тут предшественником теоретической географии как науки, а не, допустим, конкретного ученого, ассоциируюшего себя с теоретической географией. Такая аттестация Вениамина Петровича неуместно уничижительна: сам В.П. Семёнов-Тян-Шанский, несомненно, являлся теоретико-географом (может быть, первым в России), а не предтечей того, что вразнобой называют теоретической географией его внучатые последователи.

${ }^{17}$ Почетными гостями заседания были д.б.н. О.И. СемёновТян-Шанский (зам. директора Лапландского заповедника, племянник ученого), В.В. и А.В. Семёновы-Тян-Шанские (невестка и внучка), а также В.А. Мещеряков - директор народного музея П.ІІ. Семёнова-Тян-Шанского в деревне Гремячка Рязанской области.
} 
чатым племянником ученого [60] До этого в периодике выходили отдельные фрагменты этой фундаментальной рукописи [53, 54, 57, 58]. Их появление в цельной книжной форме еще более тесно связало имя и судьбу Вениамина Петровича с именем и судьбой Петра Петровича СемёноваТян-Шанского. Мемуары сына вполне можно рассматривать и как некое продолжение мемуаров его отца.

Тогда же, в 2009 г., вышла книга А.И. Трейвиша "Город, район, страна и мир. Развитие России глазами страноведа" [62]. Судя по одному лишь названию, она могла бы показаться рефлексией на "Район и страну”, но это не так. У двух авторов совершенно разные материи - теоретическая у В.П. Семёнова-Тян-Шанского и эмпирическая у А.И. Трейвища. От Вениамина Петровича Трейвиш взял “таксономичность", преобразовав ее в “полимасштабность", идею которой, в свою очередь, он воспринял от другого географа-классика и своего университетского учителя - Исаака Моисеевича Маергойза, автора двух незавершенных теорий - территориальных структур и экономико-географического положения.

В 2017 г. увидели свет факсимильное переиздание книги “Район и страна", а также материалы "VI Семёновских чтений", состоявшихся в Липецке в 2017 г. В книгу вошло сразу три статьи, целиком или частично посвященные В.П. Семёнову-Тян-Шанскому [18, 20, 25].

\section{ЗАКЛЮЧЕНИЕ}

Вениамин Петрович Семёнов-Тян-Шанский прожил яркую жизнь в науке, многие его идеи и замыслы и в наши дни звучат современно, а некоторые (например, центрография и дазиметрическое картографирование) - и злободневно.

Его научное наследие - национальное российское достояние и гордость. И то, что ни страна, ни профессиональное географическое сообщество не отметило этот 150-летний юбилей достойно конференциями или изданиями, - огорчительно.

Впрочем, кто сказал, что для этого непременно нужен юбилей?

Представляется, что лучшим выходом из положения был бы выпуск комментированного издания избранных работ В.П. Семёнова-Тян-Шанского.

Возможный вариант названия, обнимающего весь спектр содержания книги: "Город, деревня, район и страна. Избранные работы по антропогеографии и теоретической географии". В нее вошли бы прежде всего четыре главные книги Вениамина Петровича - "Город и деревня в Европейской России” [46], “Антропогеография Центральной промышленной области" [50], “Район и страна” [51] и “Географические законы. Опыт высшей геогра- фии". Плюс лучшие из тех его опубликованных и неопубликованных статей, которые не перекрываются книжными текстами.

\section{БЛАГОДАРНОСТИ}

Автор благодарит Фонд наследия П.П. СемёноваТян-Шанского за предоставленные иллюстрации, а также А.И. Алексеева, А.И. Гурова, А.В. Кобака, М.Б. Матвееву, Б.Б. Родомана и А.И. Трейвиша за обсуждение и другую помощь.

\section{ACKNOWLEDGMENTS}

The author thanks the P.P. Semyonov-Tyan-Shansky Heritage Foundation for the provided illustrations, as well as A.I. Alekseev, A.I. Gurov, A.V. Kobak, M.B. Matveeva, B.B. Rodoman and A.I. Treivish for the discussions and other assistance.

\section{СПИСОК ЛИТЕРАТУРЫ}

1. Агирречу A.A. Пятнадцать лет Ковалёвских чтений // Вопросы географии. Сб. 135. География населения и социальная география / Отв. ред. А.И. Алексеев, А.А. Ткаченко. М.: Издательский дом “Кодекс", 2013. C. 537-543.

2. Баранский Н.Н. Памяти В.П. Семёнова-Тян-Шанского // География в школе. 1946. № 1. С. 49-50.

3. Баранский Н.Н. Страноведение и география физическая и экономическая // Изв. ВГО. 1946. Т. 78. № 1. C. 9-24.

4. Берг Л.С. Вениамин Петрович Семёнов-Тян-Шанский: К 25-летию его научной деятельности // Землеведение. 1917. Вып. 3/4. С. 47-48.

5. Берг Л.С. Вениамин Петрович Семёнов-Тян-Шанский: К 70-летию со дня рождения // Изв. ВГО. 1940. T. 72. № 3. С. $366-370$.

6. Беседа на высоте птичьего полета / Интервью с Б.Б. Родоманом, взятое О. Балла и А. Левинтовым // Знание - сила. 2011. № 2. С. 61-66.

7. Бобрик A.A. Немного геометрии в методологии географии: К 35-летию научной и творческой работы Вениамина Петровича Семёнова-Тян-Шанского // Информация Центрографической лаборатории им. Д.И. Менделеева. Л., 1928. С. 5.

8. Богданов А.А. Из истории присвоения П.П. Семёнову почетной приставки “Тян-Шанский" / VI Семеновские чтения: Наследие П.П. СеменоваТян-Шанского и современная наука: Материалы Международной науч. конф., посвященной 190летию со дня рождения П.П. Семенова-Тян-Шанского (19-20 мая 2017 г., Липецк) / Отв. ред. Н.В. Федина. Липецк: ЛГПУ им. П.П. СеменоваТян-Шанского, 2017. С. 15-18.

9. Борейко В.E. К 120-летию со дня рождения В.П. Семёнова-Тян-Шанского // Изв. ВГО. 1990. Т. 122. Вып. 4. С. 380-382.

10. Борейко В. Краеведческое движение и охрана природы (20-30-е годы) // Изв. ВГО. 1991. Т. 123. Вып. 3. С. 225-232. 
11. География в наследство: как Вениамин СемёновТян-Шанский продолжал дело отца / Интервью О. Ладыгиной с П. Поляном // Русское географическое общество. Сайт. 2020. 8 апреля. https://www.rgo.ru/ru/article/geografiya-v-nasledstvokak-veniamin-semyonov-tyan-shanskiy-prodolzhal-delootca

12. Глезер О.Б., Полян П.М. К 75-летию выхода в свет книги "Город и деревня в Европейской России" В.П. Семёнова-Тян-Шанского // Изв. ВГО. 1986. № 5. C. 448-451.

13. Гловели Г.Д. Геополитическая экономия в России: от дискуссий о самобытности к глобальным моделям. СПб.: Алетейя, 2009. 204 с.

14. Гловели Г.Д. Пути обеспечения державного положения России в работах Д.И. Менделеева и В.П. Семёнова-Тян-Шанского // Федерализм. 2008. № 4. C. 183-200.

15. Гловели Г.Д. Российские экономико-геополитические школы // Мировая экономика и международные отношения. 2010. № 11. С. 37-49.

16. Ефремов Ю.К. Из истории создания географических музеев // Жизнь Земли. М., 1967. Сб. 4. С. 244-255.

17. Город и деревня в Европейской России: сто лет перемен. Памяти Вениамина Петровича СемёноваТян-Шанского / Автор идеи: П.М. Полян / Ред.сост:. Т.Г. Нефедова, П.М. Полян, А.И. Тревйиш. М.: ОГИ, 2001. 586 с.

18. Гусаков Т.Ю. “Район и страна" В.П. СемёноваТян-Шанского для отечественной теоретической географии / VI Семёновские чтения: Наследие П.П. Сёменова-Тян-Шанского и современная наука: Материалы Международной науч. конф., посвященной 190-летию со дня рождения П.П. Семёнова-Тян-Шанского (19-20 мая 2017 г., Липецк) / Отв. ред. Н.В. Федина. Липецк: ЛГПУ им. П.П. Семёнова-Тян-Шанского, 2017. С. 22-24.

19. Каганский В.Л. Пространство в исследованиях Б.Б. Родомана и ученых его школы // Изв. РАН. Сер. геогр. 2009. № 2. С. 112-120.

20. Каганский В.Л. Гумбольдт - Риттер - Семёновы: российская теоретическая география ландшафта / VI Семёновские чтения: Наследие П.П. СемёноваТян-Шанского и современная наука: Материалы Международной науч. конф., посвященной 190летию со дня рождения П.П. Семёнова-Тян-Шанского (19-20 мая 2017 г., Липецк) / Отв. ред. Н.В. Федина. Липецк: ЛГПУ им. П.П. СемёноваТян-Шанского, 2017. С. 25-27.

21. Каганский В.Л., Полян П.М., Родоман Б.Б. “Район и страна” В.П. Семёнова-Тян-Шанского: современное звучание и значение (к пятидесятилетию выхода книги в свет) // Изв. АН СССР. 1979. № 3. С. $122-129$.

22. Каганский В.Л., Полян П.М., Родоман Б.Б. “Район и страна" В.П. Семёнова-Тян-Шанского // Родоман Б.Б. География. Районирование. Картоиды: Сб. трудов. Смоленск, 2007. С. 331-340.

23. Константинов O.A. К столетию Вениамина Петровича Семёнова-Тян-Шанского // Изв. ВГО. 1970. T. 102. № 5. C. 473-483.

24. Ковалев С.А., Коровицын В.П., Ковальская Н.Я., Саушкин Ю.Г. Вениамин Петрович Семёнов-Тян-
Шанский: К столетию со дня рождения // Вестн. Моск. ун-та. Сер. 5. География. 1970. № 4. С. 115116.

25. Лучников А.С. В.П. Семёнов-Тян-Шанский и его работы в области географии промышленности / VI Семёновские чтения: Наследие П.П. СемёноваТян-Шанского и современная наука: Материалы Международной науч. конф., посвященной 190летию со дня рождения П.П. Семёнова-Тян-Шанского (19-20 мая 2017 г., Липецк) / Отв. ред. Н.В. Федина. Липецк: ЛГПУ им. П.П. СемёноваТян-Шанского, 2017. С. 27-29.

26. Новиченок А.C. О картах плотности населения В.П. Семёнова-Тян-Шанского // Исследования по проблемам геодезии и картографии. Иркутск, 1973. С. $129-139$

27. Покшишевский В.В. Вениамин Петрович СемёновТян-Шанский: Вместо некролога // Изв. ВГО. 1942. T. 74. С. 58-60.

28. Полян П.М. У истоков российской географии населения и городов (К 75-летию выхода "Города и деревни в Европейской России" и "Торговли и промышленности Европейской России” В.П. Семёнова-Тян-Шанского) // Изв. АН СССР. Сер. геогр. 1988. № 4. С. 126-131.

29. Полян П.М. Вениамин Петрович Семёнов-ТянШанский. 1870-1942. (Сер.: Научные биографии). М.: Наука, 1989. 127 с.

30. Полян П.М. “Любимое детище...” В.П. СемёноваТян-Шанского: Судьба Географического музея // Природа. 1989. № 3. С. 83-91.

31. Полян П.М. В.П. Семёнов-Тян-Шанский и Центральный Географический Музей // Наука и власть. М.: Ин-т философии АН СССР, 1990. C. 117-141.

32. Полян П.М. Судьба В.П. Семёнова-Тян-Шанского и разгром Центрального географического музея // Наука и тоталитарная власть. Философские исследования. 1993. № 3. С. 187-206.

33. Полян П.М. "Город и деревня в Европейской России" В.П. Семёнова-Тян-Шанского глазами современников и потомков // Город и деревня в Европейской России: сто лет перемен. М., 2001. C. $21-32$.

34. Полян П.М. Возрождение через столетие? Дазиметрические карты В.П. Семёнова-Тян-Шанского и их перспективы в информационном поле XXI века // Изв. АН. 2012. № 6. С. 98-106.

35. Полян П.М. Вениамин Петрович Семёнов-ТянШанский - последний могиканин гумбольдтовской географии // Географические арабески: пространства вдохновения, свободы и несвободы. М.: Икар, 2017. С. 241-320.

36. Полян П.М. В гробу, сколоченном из письменного стола. К 150-летию со дня рождения Вениамина Петровича Семёнова-Тян-Шанского // Colta.ru. 2020. 8 апреля. https://www.colta.ru/articles/specials/ 24026-zhizn-i-smert-velikogo-geografa-k-150-letiyuveniamina-semenova-tyan-shanskogo

37. Полян П.М. “Круг географии” и судьба географа. К 150 -летию со дня рождения Вениамина Петровича Семёнова-Тян-Шанского // Институт географии РАН. 2020. 8 апреля. http://igras.ru/news/2413 
38. Полян П., Приходько Р. Дазиметрические карты В.П. Семёнова-Тян-Шанского и их перспективы в информационном поле XXI в. // Миграции и пространственная мобильность в сельско-городском континууме России в XX в.: управляемость, адаптивность и стратегии преодоления. Российско-немецкая научная конференция (Ставрополь, 15-19 июня 2011 г.): Сб. рабочих материалов. Ставрополь-Фрайбург: СГУ, 2011. С. 194-202.

39. Поспелов E.M. Топонимика в трудах В.П. Семёнова-Тян-Шанского // Вопросы географии. М., 1966. Вып. 70: Изучение географических названий. C. 97-102.

40. Речь В.П. Семёнова-Тян-Шанского в селе Михайловском, сент. 1924 / Публ. и вступ. заметка П.М. Поляна // Вопросы литературы. 1979. № 6. С. 154-158.

41. Родоман Б.Б. Способы индивидуального и типологического районирования и их изображение на карте // Физико-географическое районирование / Вопросы географии. М.: Географгиз, 1956. Сб. 39. C. 28-69.

42. Родоман Б.Б. Территориальные ареалы и сети. Очерки теоретической географии. Смоленск: Ойкумена, 1999. 256 с.

43. Родоман Б.Б. География. Районирование. Картоиды: Сб. трудов. Смоленск: Ойкумена, 2007. 372 с.

44. Саушкин Ю.Г. Экономическая география: история, теория, методы, практика. М.: Мысль, 1973. C. $74-77$.

45. Святловский E.E. К тридцатипятилетию научной деятельности В.П. Семёнова-Тяп-Шанского. Важнейшие работы В.П. Семёнова-Тян-Шанского. Проф. В.П. Семёнов-Тян-Шанский: (Важнейшие вехи деятельности) // Информация Центрографической лаборатории им. Д.И. Менделеева. Л., 1928. С. 1-4.

46. Семёнов-Тян-Шанский В.П. Город и деревня в Европейской России: Очерк по экономической географии с 16 картами и картограммами / Под ред. В.О. Струве // Зап. ИРГО по отделению статистики. 1910. Т. 10. Вып. 2. 212 с.

47. Семёнов-Тян-Шанский В.П. О могущественном территориальном владении применительно к России // Изв. РГО. Т. 51. 1915. Вып. 8. С. 425-458.

48. Семёнов-Тян-Шанский В.П. Что такое география? // Изв. РГО. Т. 51. 1915. Вып. 9. С. 476-477.

49. Семёнов-Тян-Шанский В.П. Дазиметрическая карта Европейской России. Масштаб: 1 : 420 000. Пг.; Л., 1923-1927. 47 л.

50. Семёнов-Тян-Шанский В.П. Антропогеография Центральной промышленной области: Распределение населения ЦПО в связи с естественными условиями. Л.: Научно-технический отдел Высшего совета народного хозяйства СССР, 1924. 26 с.

51. Семенов-Тян-Шанский В.П. Район и страна: Пособие для высшей школы. М.-Л.: Государственное издательство, 1928. 312 с.

52. Семёнов-Тян-Шанский В.П. Разбор поэмы “Слово о полку Игореве” / Публ. и вступ. заметка П.М. Поляна // Альманах библиофила. М., 1986. Вып. 22. С. 257-267.
53. Семёнов-Тян-Шанский В.П. Несентиментальное путешествие / Предисл. и публ. П.М. Поляна // Вокруг света. 1990. № 10. С. 37-43.

54. Семёнов-Тян-Шанский В.П. Воспоминания (отрывки из глав, посвященных революции и разрухе) / Публ. Ф. Благовещенского // Звенья. М., 1992. Вып. 2. С. 395-423.

55. В.П. Семёнов-Тян-Шанский и П.А. Кропоткин (обмен письмами в 1920 г.) / Публ., предисл. и примеч. А.В. Бирюкова и П.М. Поляна // Труды Комиссии по научному наследию П.А. Кропоткина. М., 1992. Вып. 2. С. 175-184.

56. Семёнов-Тян-Шанский В.П. О могущественном территориальном владении применительно к России // Федерализм. 1996. № 2. Разделы II-IV. С. 148-163.

57. Семёнов-Тян-Шанский В.П. То, что прошло: Главы из книги воспоминаний (Дедовский дом (до 1870); Наши игры (1873-1879); Дедовская квартира (1870-1888)) / Предисл. и публ. М.А. СемёноваТян-Шанского // Невский архив: Историко-краеведческий сборник. СПб.: Лики России, 2003. Вып. VI. C. 5-78.

58. Семёнов-Тян-Шанский В.П. То, что прошло: Главы из книги воспоминаний (Обучение в гимназии) / Предисл. и публ. М.А. Семёнова-Тян-Шанского // Невский архив: Историко-краеведческий сборник. СПб.: Лики России, 2006. Вып. VII. С. 5-86.

59. Семёнов-Тян-Шанский В.П. О могущественном территориальном владении применительно к России // Пространственная экономика. 2008. № 2. Разделы III и IV. C. 144-160.

60. Семёнов-Тян-Шанский В.П. То, что прошло. В 2-х томах / Сост. М.А. Семёнов-Тян-Шанский; послесловие и приложения - П.М. Полян. М.: Новый хронограф, 2009. Т. 1. 1870-1917. 678 с.; Т. 2. 1917-1942. $664 \mathrm{c}$.

61. Семёнов-Тян-Шанский В.П. О могущественном территориальном владении применительно к России // Демоскоп weekly. 2020. № 853-854. 30 марта-12 апреля. http://www.demoscope.ru/weekly/2020/0853/nauka07.php

62. Трейвиш А.И. Город, район, страна и мир. Развитие России глазами страноведа. М.: Новый хронограф, 2009. 373 c.

63. Трейвиш А.И. Как нас теперь называть (о содержании и наименовании нашей науки) // Вестн. Ассоциации российских географов-обществоведов. 2012. № 1. C. 5-19.

64. Хорев Б.С. Обзор работы комиссии географии населения и городов Московского филиала Географического общества Союза ССР (1945-1957 гг.) // Вопросы географии. 1959. Сб. 45. С. 227-245.

65. Kagansky V., Polyan P., Rodoman B. V.P. SemenovTyan-Shanskiy's "Region and Country": Its Present Day Relevance and Meaning (on the 50th Anniversary of Publication) // Soviet Geography. 1980. № 6. P. 355-363. 


\title{
"The Circle of Geography" and the Fate of the Anthropogeographer: To the 150th Anniversary of Veniamin Petrovich Semyonov-Tyan-Shansky
}

\author{
P. M. Polian 1, 2, * \\ ${ }^{1}$ National Research University Higher School of Economics, Moscow, Russia \\ ${ }^{2}$ Institute of Geography, Russian Academy of Sciences, Moscow, Russia \\ *e-mail: pavel.polian@gmail.com
}

\begin{abstract}
The article is dedicated to the 150th anniversary of the birth of the prominent Russian geographer Veniamin Petrovich Semyonov-Tyan-Shansky (April 8, 1870-February 10, 1942) and re-designated the key moments of his scientific formation, the most important of which is "Circle of Geography" concept. Semyonov-TyanShansky developed the concept in 1913, and it determined the main milestones of scientist's evolution (this "Circle" he would like to have written on its tombstone). His unpublished text "About the missing elements in the adopted system of dividing geography into mathematical, physical, economic and political ones" (dated April 21, 1937) is brought in the scientific discourse for the first time. The article formulates the main directions of posthumous perception and high appreciation of the geographical heritage of Semyonov-TyanShansky by his scientific contemporaries and descendants, shows the continuality in relation to him of the theoretical and geographical work of B.B. Rodoman. The necessity of the critical edition of works of Semyonov-Tyan-Shansky, which would include both his main published ("The Region and the Country"), and not published ("Geographical Laws. Experience of the Higher Geography") works is discussed.
\end{abstract}

Keywords: Veniamin Petrovich Semyonov-Tyan-Shansky, biography, theoretical geography, anthropogeography, B.B. Rodoman, history of geography

\section{REFERENCES}

1. Agirrechu A.A. Fifteen years of Kovalev's readings. In Voprosy Geografii [Problems of Geography]. Vol. 135: Geografiya naseleniya i sotsial'naya geografiya [Population Geography and Social geography]. Alekseev A.I., Tkachenko A.A., Eds. Moscow: Kodeks Publ., 2013, pp. 537-543. (In Russ.).

2. Baranskii N.N. To the memory of V.P. Semenov-TyanShansky. Geografiya v Shkole, 1946, no. 1, pp. 49-50. (In Russ.).

3. Baranskii N.N. Country studies and geography, physical and economic. Izv. Vses. Geogr. O-va, 1946, vol. 78, no. 1, pp. 9-24. (In Russ.).

4. Berg L.S. Veniamin Petrovich Semenov-Tyan-Shansky: To the 25th anniversary of his scientific activity. Zemlevedenie, 1917, nos. 3-4, pp. 47-48. (In Russ.).

5. Berg L.S. Veniamin Petrovich Semenov-Tyan-Shansky: To the 70th anniversary of his birth. Izv. Vses. Geogr. $O-v a$, 1940, vol. 72, no. 3, pp. 366-370. (In Russ.).

6. Talk at a bird's-eye view. Interview with B.B. Rodoman, taken by O. Balla and A. Levintov. Znanie - Sila, 2011, no. 2, pp. 61-66. (In Russ.).

7. Bobrik A.A. A little geometry in geography methodology: To the 35th anniversary of the scientific and creative work of Veniamin Petrovich Semenov-TyanShansky. In Informatsiya Tsentrograficheskoi laboratorii im. D.I. Mendeleeva [Information of the D.I. Mendeleev Centrographic Laboratory]. Leningrad, 1928, 5 p. (In Russ.).

8. Bogdanov A.A. From a history of assignment of honorary prefix "Tyan-Shansky" to P.P. Semenov. In VI Semenovskie chteniya: Nasledie P.P. Semenova-TyanShanskogo i sovremennaya nauka [VI Semenov Readings: The Legacy of P.P. Semenov-Tian-Shansky and Modern Science]. Lipetsk: Lipetsk. Gos. Ped. Univ. im. P.P. Semenova-Tyan-Shanskogo, 2017, pp. 15-18. (In Russ.).

9. Boreiko V.E. To the 120th anniversary of V.P. Semenov-Tyan-Shansky. Izv. Vses. Geogr. O-va, 1990, vol. 122 , no. 4 , pp. 380-382. (In Russ.).

10. Boreiko V. Local history movement and nature protection (1920-30s years). Izv. Vses. Geogr. O-va, 1991, vol. 123, no. 3, pp. 225-232. (In Russ.).

11. Geography in inheritance: how Veniamin SemenovTyan-Shansky continued his father's work. Interview of O. Ladygina with P. Polyan. Russian Geographical Society, April 8, 2020. Available at: https:// www.rgo.ru/ru/article/geografiya-v-nasledstvo-kakveniamin-semyonov-tyan-shanskiy-prodolzhal-delootca (accessed: 05.07.2020). (In Russ.).

12. Glezer O.B., Polyan P.M. To the 75th anniversary of the publication of the book "City and Village in European Russia”, V.P. Semenov-Tyan-Shansky. Izv. Vses. Geogr. $O-v a, 1986$, no. 5, pp. 448-451. (In Russ.).

13. Gloveli G.D. Geopoliticheskaya ekonomiya v Rossii: ot diskussii o samobytnosti k global'nym modelyam [Geopolitical Economy in Russia: from Discussions on Identity to Global Models]. St-Petersburg: Aleteya Publ., 2009. 204 p.

14. Gloveli G.D. Ways to ensure Russia's position of power in the works of D.I. Mendeleev and V.P. SemenovTian-Shansky. Federalism, 2008, no. 4, pp. 183-200. (In Russ.).

15. Gloveli G.D. Russian economic and geopolitical schools. Mirovaya Ekonomika i Mezhdunarodnye Otnosheniya, 2010, no. 11, pp. 37-49. (In Russ.).

16. Efremov Yu.K. From the history of creation of geographical museums. Zhizn'Zemli,1967, no. 4. pp. 244255. (In Russ.).

17. Gorod i derevnya v Evropeiskoi Rossii: sto let peremen. Pamyati Veniamina Petrovicha Semenova-Tyan-Shans- 
kogo [City and Village in European Russia: Hundred Years of Changes. To the Memory of Veniamin Petrovich Semenov-Tyan-Shansky]. Nefedova T.G., Polyan P.M., Treivish A.I., Eds. Moscow: OGI Publ., 2001. 586 p.

18. Gusakov T.Yu. "Rayon and country" by V.P. SemenovTyan-Shansky for Russian theoretical geography. In VI Semenovskie chteniya: Nasledie P.P. Semenova-TyanShanskogo i sovremennaya nauka [VI Semenov Readings: The Legacy of P.P. Semenov-Tyan-Shansky and Modern Science]. Lipetsk: Lipetsk. Gos. Ped. Univ. im. P.P. Semenova-Tyan-Shanskogo, 2017, pp. 22-24. (In Russ.).

19. Kagansky V.L. Space in investigations of B.B. Rodoman and scientists of his school. Izv. Akad. Nauk, Ser. Geogr., 2009, no. 2, pp. 112-120. (In Russ.).

20. Kagansky V.L. Humboldt - Ritter - Semenovs: Russian theoretical geography of landscape. In VI Semenovskie chteniya: Nasledie P.P. Semenova-Tyan-Shanskogo $i$ sovremennaya nauka [VI Semenov Readings: The Legacy of P.P. Semenov-Tyan-Shansky and Modern Science]. Lipetsk: Lipetsk. Gos. Ped. Univ. im. P.P. Semenova-Tyan-Shanskogo, 2017, pp. 25-27. (In Russ.).

21. Kagansky V.L., Polyan P.M., Rodoman B.B. "Rayon and country", V.P. Semenov-Tyan-Shansky: Modern sound and significance (for fiftieth anniversary of the book publication). Izv. Akad. Nauk, Ser. Geogr., 1979, no. 3, pp. 122-129. (In Russ.).

22. Kagansky V.L., Polyan P.M., Rodoman B.B. "District and country" by V.P. Semenov-Tyan-Shansky. In Rodoman B.B. Geografiya. Raionirovanie. Kartoidy: Sbornik trudov [Geography. Zoning. Cartoids: Collection of Works]. Smolensk: Oikumena Publ., 2007, pp. 331-340. (In Russ.)

23. Konstantinov O.A. By the centenary of Veniamin Petrovich Semenov-Tyan-Shansky. Izv. Vses. Geogr. O$v a$, 1970, vol. 102, no. 5, pp. 473-483. (In Russ.).

24. Kovalev S.A., Korovitsyn V.P., Koval'skaya N.Y., Saushkin Yu.G. Veniamin Petrovich Semenov-Tian-Shansky: To centenary from the birth. Vestn. Mosk. Gos. Univ., Ser. 5: Geogr., 1970, no. 4, pp. 115-116. (In Russ.).

25. Luchnikov A.S. V.P. Semenov-Tyan-Shansky and his work in the field of geography of industry. In $V I S e-$ menovskie chteniya: Nasledie P.P. Semenova-TyanShanskogo i sovremennaya nauka [VI Semenov Readings: The Legacy of P.P. Semenov-Tyan-Shansky and Modern Science]. Lipetsk: Lipetsk. Gos. Ped. Univ. im. P.P. Semenova-Tyan-Shanskogo, 2017, pp. 27-29. (In Russ.).

26. Novichenok A.S. About the V.P. Semenov-Tyan Shansky population density maps. In Issledovaniya po problemam geodezii i kartografii [Research on Geodesy and Cartography]. Irkutsk, 1973, pp. 129-139. (In Russ.).

27. Pokshishevskii V.B. Veniamin Petrovich SemenovTyan-Shansky: Instead of an obituary. Izv. Vses. Geogr. $O-v a$, 1942, vol. 74, pp. 58-60. (In Russ.).

28. Polyan P.M. At the origins of Russian geography of population and cities (to the 75th anniversary of "Cities and Villages in European Russia" and "Trade and Industry of European Russia" by V.P. Semenov-TyanShansky). Izv. Akad. Nauk, Ser. Geogr., 1988, no. 4, pp. 126-131. (In Russ.).
29. Polyan P.M. Veniamin Petrovich Semenov-TyanShanskii 1870-1942 [Veniamin Petrovich SemenovTyan-Shansky. 1870-1942]. Moscow: Nauka Publ., 1989. $127 \mathrm{p}$.

30. Polyan P.M. "Favorite child..." of V.P. Semenov-TyanShansky: Destiny of Geographical Museum. Priroda, 1989, no. 3, pp. 83-91. (In Russ.).

31. Polyan P.M. V.P. Semenov-Tyan-Shansky and Central Geographical Museum. In Nauka $i$ vlast' [Science and Power]. Moscow: Inst. Filosofii Akad. Nauk SSSR, 1990, pp.117-141. (In Russ.).

32. Polyan P.M. Fate of V.P. Semenov-Tyan-Shansky and defeat of Central Geographical Museum. Nauka i Totalitarnaya Vlast'. Filosofskie Issled., 1993, no. 3, pp. 187-206. (In Russ.).

33. Polyan P.M. "City and Village in European Russia" by V.P. Semenov-Tyan-Shansky through the eyes of contemporaries and descendants. In Gorod i derevnya $v$ Evropeiskoi Rossii: sto let peremen. Pamyati Veniamina Petrovicha Semenova-Tyan-Shanskogo [City and Village in European Russia: Hundred Years of Changes. To the Memory of Veniamin Petrovich Semenov-Tyan-Shansky]. Nefedova T.G., Polyan P.M., Treivish A.I., Eds. Moscow: OGI Publ., 2001, pp. 21-32. (In Russ.).

34. Polyan P.M. Dazimetric maps of V.P. Semenov-TyanShansky and their prospects in the information field of the 21 Century. Izv. Akad. Nauk, Ser. Geogr., 2012, no. 6, pp. 98-106. (In Russ.).

35. Polyan P.M. Veniamin Petrovich Semenov-TyanShansky - the last Mohican of Humboldt's Geography. In Geograficheskie arabeski: prostranstva vdokhnoveniya, svobody $i$ nesvobody [Geographical Arabesques: Spaces of Inspiration, Freedom and Unfreedom]. Moscow: Ikarus Publ., 2017, pp. 241-320. (In Russ.).

36. Polyan P.M. In a Coffin, Made from a Writing Table. To the 150th Anniversary of the Birth of Veniamin Petrovich Semenov-Tyan-Shansky. Colta.ru, April 8, 2020. Available at: https://www.colta.ru/articles/specials/24026-zhizn-i-smert-velikogo-geografa-k-150letiyu-veniamina-semenova-tyan-shanskogo (accessed: 07.07.2020). (In Russ.).

37. Polyan P.M. "Circle of geography" and destiny of geographer. To the 150th anniversary of Veniamin Petrovich Semenov-Tyan-Shansky. Inst. Geogr., RAS, April 8, 2020. Available at: http://igras.ru/news/2413 (accessed: 07.07.2020). (In Russ.).

38. Polyan P.M., Prikhod'ko R. Dasimetric maps of V.P. Semenov-Tyan-Shansky and their prospects in information field of XXI century. In Migratsii i prostranstvennaya mobil'nost' $v$ sel'sko-gorodskom kontinuume Rossii v XX v.: upravlyaemost', adaptivnost' $i$ strategii preodoleniya. Ross.-nemetskaya nauchn. konf. (Stavropol', 15-19 iyunya 2011 g.) [Migration and Spatial Mobility in Rural-Urban Continuum of Russia in XX Century: Controllability, Adaptivity and Overcoming Strategies. Russian-German Sci. Conf. (Stavropol, 15-19 June 2011)]. Stavropol: Stavropol. Gos. Univ., 2011, pp. 194-202. (In Russ.).

39. Pospelov E.M. Toponomy in the works of V.P. Semenov-Tian-Shansky. In Voprosy Geografii [Problems of Geography]. Vol. 70: Izuchenie geograficheskikh nazvanii [Study of Geographical Names]. M., 1966, pp. 97-102. (In Russ.). 
40. Speech by V.P. Semenov-Tyan-Shansky in the village of Mikhailovskoe, September 1924 (Publ. and preface by P.M. Polyan). Vopr. Literatury, 1979, no. 6, pp. 154158. (In Russ.).

41. Rodoman B.B. Methods of individual and typological zoning and their image on the map. In Voprosy geografii [Problems of Geography]. Vol. 39: Fiziko-geograficheskoe raionirovanie [Physical and Geographical Zoning]. Moscow: Geografgiz Publ., 1956, pp. 28 - 69. (In Russ.).

42. Rodoman B.B. Territorial'nye arealy i seti. Ocherki teoreticheskoi geografii [Territorial Areas and Networks. Essays of Theoretical Geography]. Smolensk: Oikumena Publ., 1999. 256 p.

43. Rodoman B.B. Geografiya. Raionirovanie. Kartoidy: Sbornik trudov [Geography. Zoning. Cartoids: Collection of Works]. Smolensk: Oikumena Publ., 2007. 372 p. (In Russ.).

44. Saushkin Yu.G. Ekonomicheskaya geografiya: istoriya, teoriya, metody, praktika [Economic Geography: History, Theory, Methods, Practice]. Moscow: Mysl' Publ., 1973, pp. 74-77.

45. Svyatlovskii E.E. To the thirty-fifth anniversary of the scientific activity of V.P. Semenov-Tyan-Shansky. The most important works of V.P. Semenov-Tyan-Shansky. Prof. V.P. Semenov-Tyan-Shansky: (The Most Important Milestones of Activity). In Informatsiya Tsentrograficheskoi laboratorii im. D.I. Mendeleeva [Information of Centrographic Laboratory named after D.I. Mendeleev]. Leningrad, 1928, pp. 1-4. (In Russ.).

46. Semenov-Tyan-Shansky V.P. Gorod i derevnya v Evropeiskoi Rossii: Ocherk po ekonomicheskoi geografii s 16 kartami i kartogrammami [City and Village in European Russia: Essay on Economic Geography with 16 Maps and Cartograms]. Struve V.O., Ed. St. Petersburg: Russ. Imper. Geogr. O-vo, 1910. 212 p.

47. Semenov-Tyan-Shansky V.P. On powerful territorial ownership in relation to Russia. Izv. Imper. Russ. Geogr. $O-v a, 1915$, vol. 51, no. 8, pp. 425-457. (In Russ.).

48. Semenov-Tyan-Shansky V.P. What is geography? Izv. Imper. Russ Geogr. O-va, 1915, vol. 51, no. 9, pp. 476477. (In Russ.).

49. Semenov-Tyan-Shansky V.P. Dasimetric Map of European Russia. Scale: 1 : 420000. Leningrad, 1923-1927. 47 p. (In Russ.).

50. Semenov-Tyan-Shansky V.P. Antropogeografiya Tsentral'noi promyshlennoi oblasti: Raspredelenie naseleniya TsPO v svyazi s estestvennymi usloviyami [Anthropogeography of the Central Industrial Region (CIP): Population Distribution of CIP in Relation to Natural Conditions]. Leningrad, 1924. 26 p.

51. Semenov-Tyan-Shansky V.P. Raion i strana: Posobie dlya vysshei shkoly [District and Country: Handbook for Higher School]. M., 1928. 312 p. (In Russ.).

52. Semenov-Tyan-Shansky V.P. Analysis of the poem "The Tale about Igor's Campaign" (Publ. and preface by P.M. Polyan). Al'manakh Bibliofila, 1986, no. 22, pp. 257-267. (In Russ.).

53. Semenov-Tyan-Shansky V.P. Non-sentimental journey (Publ. and preface by P.M. Polyan). Vokrug Sveta, 1990, no. 10, pp. 37-43. (In Russ.).
54. Semenov-Tyan-Shansky V.P. Memoirs (excerpts from the chapters on revolution and destruction. Publ. by F. Blagoveshchenskii). Zven'ya, 1992, no. 2, pp. 395-423. (In Russ.).

55. V.P. Semenov-Tyan-Shansky and P.A. Kropotkin (exchange of letters in 1920) (Publ., preface and notes by A.V. Biryukov and P.M. Polyan). Tr. Komissii po Nauchn. Naslediyu P.A. Kropotkina, 1992, no. 2, pp. 175-184. (In Russ.).

56. Semenov-Tyan-Shansky V.P. On powerful territorial possession in relation to Russia. Federalism, 1996, no. 2, pp. 148-163. (In Russ.).

57. Semenov-Tyan-Shansky V.P. What has passed: Chapters from the book of memoirs [Grandfather's House (until 1870); Our games (1873-1879); Grandfather's apartment (1870-1888)] (Publ. and preface by M.A. Semenov-Tyan-Shansky). In Nevskii arkhiv: Istorikokraevedcheskii sbornik [Neva Archive: Local History]. St. Petersburg: Liki Rossii Publ., 2003, vol. 6, pp. 5-78. (In Russ.).

58. Semenov-Tyan-Shansky V.P. What has passed: Chapters from the book of memoirs [Teaching in the gymnasium] (Publ. and preface by M.A. Semenov-TyanShansky). In Nevskii arkhiv: Istoriko-kraevedcheskii sbornik [Neva Archive: Local History]. St. Petersburg: Liki Rossii Publ., 2006, vol. 7, pp. 5-86. (In Russ.).

59. Semenov-Tyan-Shansky V.P. On powerful territorial possession in relation to Russia. Prostranstvennaya Ekonomika, 2008, no. 2, pp. 144-160. (In Russ.).

60. Semenov-Tyan-Shansky V.P. To, chto proshlo [What has Passed]. 2 vols. Semenov-Tyan-Shansky M.A., Ed. Afterword and appendices by P.M. Polyan. Moscow: Novyi Khronograf Publ., 2009. vol. 1(1870-1917). 678 p.; vol. 2(1917-1942). 664 p.

61. Semenov-Tyan-Shansky V.P. On powerful territorial possession in relation to Russia. Demoskop, 2020, nos. 853-854. Available at: http://www.demoscope.ru/weekly/2020/0853/nauka07.php (accessed: 07.07.2020). (In Russ.).

62. Treivish A.I. Gorod, raion, strana i mir. Razvitie Rossii glazami stranoveda [City, District, Country and World. Development of Russia through the Eyes of a Regional Geographer]. Moscow: Novyi Khronograf Publ., 2009. $373 \mathrm{p}$.

63. Treivish A.I. What to call us now (about content and name of our science). Vestn. Assotsiatsii Ross. Geogr.Obshchestvovedov, 2012, no. 1, pp. 5-19. (In Russ.).

64. Khorev B.S. Review of the work of the commission on geography of population and cities of Moscow branch of Geographical society of the Union of Soviet Socialist Republics (1945-1957). In Vopr. Geografii [Problems of Geography]. Vol. 45: Geografiya gorodskikh i sel'skikh poselenii [Geography of Urban and Rural Settlements]. Moscow: Geografgiz Publ., 1959, pp. 227-245. (In Russ.).

65. Kagansky V., Polyan P., Rodoman B. V.P. SemenovTyan-Shanskiy's "Region and Country": Its present day relevance and meaning (on the 50th anniversary of publication). Soviet Geogr., 1980, no. 6, pp. 355-363. 